\title{
a german tRaveller IN ENGLAND IN 1683.
}

The manuscript diaries of travellers which are sometimes met with in libraries have lately begun to attract in a greater degree than formerly the attention which, from their notices of objects since lost or injured or from their mention of contemporary persons or events, or their illustration of manners, and the like, they are often found to deserve. Dr. Carl Curtius, the librarian of Lübeck, has lately printed (Lübeck, Borchers, 1890), as a contribution for the twentieth meeting of the Historical Society of the Hanse Towns, in a quarto pamphlet of forty-eight pages, a diary entitled 'Reise durch des nordwestliche Deutachland nach den Niederlanden und England im Jahre 1683,' by Jakob von Melle, a theological and historical writer of Lübeck, and the Hambarg poet Christian Heinrich Postel. They spent about five weeks in England, crossing to Dover from Calais for five shillings, and thence to London by Canterbury for sixteen shillings. In London they paid ten shillings a week for board and lodging in Warwick Lane. At Windsor, on Bunday, 14 Aug., they attended service in the chepel, where they saw the king, the Princess Anne, and the king's natural sons the dukes of Grafton and Richmond. They afterwards saw the king at dinner with the queen, the duke of York, and Prince George of Denmark. The Tower, Mint, Westminster Abbey (where they paid twopence), the Houses of Parliament, Gresham College, the Temple, Lambeth Palace, Greenwich, are among the places visited and described. Slarendon House is noticed, and the strange statement made that the chancellor was the son of a butcher, possibly by some confusion with the tradition of Wolsey's parentage. Three days were spent in Oxford, which was reached by a journey in a 'flying coach, which occupied one day and cost ten shillings. Here they lodged with one Mrs. Mountfort opposite the thestre, at whose table they met Professor Edward Bernard and Baron Sparr. The Bodleian Library is the only place described, partly from the Notitia Oxon., and some of the manuscripts and curiosities (including amongst the latter the 'Joseph's coat') exhibited to visitors are enumerated. The picture gallery then contained maps as well as portraits.

W. D. MACRAY.

CONTEMPORARY AOCOUNT OF THE BATTLE OF LA HOGUE.

THe following contemporary account of the battle of La Hogue is copied from a manuscript formerly belonging to the Sharpe family of Little Horton, near Bradford, Yorkshire, of which family was Abraham Sharpe the astronomer. The manuscript seems defective at the beginning and bears no signature, but is evidently the work of an eye-witness. 
An account of Admiral Rooke's family is supplied from another manuscript in the same collection written in 1697.

W. C. Bodlter.

On Friday $y^{2} 20^{\text {th }}$ of May 92.-Att 4 this morning we had so greatt a fogg we Could not tell whether We were Amongst English or French. At Eight itt Cleared up we found our Selves in Company of $5^{\circ}$ Adm ${ }^{l}$ of $y^{*}$ Blew and some of his Squadron, And we saw our Genll to yo Westward and $y^{\circ}$ Datch to $y^{\circ}$ Westward of him, and $y^{\circ}$ Erench to $y^{\circ}$ Westward of $y^{\circ}$ Dutch, then our Generall made yo signall for $y^{\circ}$ whole Fleett to make all $y^{*}$ Sayle we Could in pursuance of $y^{\circ}$ French for contrary to our Expectsations they Run from as, $w^{c h}$ we did all dey without getting any Advanttage of them, and in $y^{\ominus}$ Evening Anchored by reason of ye viollentt tides $\mathrm{y}^{t}$ runs in those partts, but weighed again aboutt Eleven att nightt and Conttinued our Pursuitt.

On Satturday $y^{*} 21^{\text {tf }}$ of May 82.-This morning wo Anchored att $y^{\circ}$ month of $y^{\circ}$ Race of Blanchard wch runs between Cape $\mathrm{L}_{\mathrm{a}}$ Hogue and $y^{\circ}$ Island of Alderne, the French flleet being att an Anchor in $y^{\circ}$ Race, aboutt Ten of $y^{\circ}$ Clock this morning Sirtoen Bayle of their Men of War drove from their Anchors to $y^{\circ}$ Eastward, Beven or Eight Seyle of them being Three deck Ships, $5^{\circ}$ Adm" "f France being one of them. Immediattly our Adm" accompanyed $w^{\text {th }}$ four English Flage more, And three or four of $y^{e}$ Dutoh Flags more Cutt and parsued Them, and left $\mathrm{Br}$ John Ashby and $y^{*}$ Adm $^{11}$ of Holland $w^{\text {th }}$ two or three Dutch Flags more $w^{\text {th }} y^{\circ}$ Remainder of $y^{\circ}$ Fleett to Pursue $y^{\circ}$ rest woh $\mathrm{He}$ did and took a ffrench Fireshp butt Could not Come up w $^{\text {th }} y^{\circ}$ Men of War all day, On $y^{\circ}$ other side $y^{0}$ Gen" Pursued $y^{\circ} \mathrm{Adm}^{11}$ of France so Close $\mathrm{y}^{\mathrm{t}}$ for fear of being taken he ran his Ship ashore in Cherbourg Bay, Two throe deok Ships doeing $y^{0}$ Like there also, woh $y^{0}$ Gener ${ }^{n}$ seeing He ordered $\mathbf{S}^{r}$ Ralph Dallivall, $w^{\text {th }}$ aboutt Ten Sayle of Men of War, and ffireshps to Attemp yo burning of them, and pursued $y^{\circ}$ Other Thirteen sayle who stood to $y^{\circ}$ Eastrd. In Pursuance of $y^{\circ}$ Orders $\mathrm{S}^{r}$ Ralph had read, he stood into $y^{*}$ Bay $w^{\text {th }}$ Three or four fourth rates ffriggats \& two ffireshps In Order to barn yo Aforesaid French Men of War, butt they read him so Warmly $y^{t}$ after an Obstinate fightt on both Sides He was forced to Come out without doing Execution.

On Sunday $y^{\circ}$ 22 of May 82.-This morning Br John Ashby had Lost sightt of $\mathrm{y}^{\mathrm{t}}$ Partt of $\mathrm{y}^{\circ}$ French Fleett He was Left to pursue, so he Tacked and stood to $y^{\circ}$ Eestward in order to Joyn ye Generall, And this day $\mathrm{Sr}^{\mathrm{r}}$ Ralph Dellivall stood into $\mathrm{y}^{\circ}$ Bay again $w^{\text {th }}$ Four or five Bayle of Third Retes and some fireshps in Order once more to Attemp yo Barning of $y^{\circ}$ aforesaid Ships $W^{\text {th }}$ after a very sharp dispute he effectted $y^{*}$ Ships Names was $y^{*}$ Royll Sun of a Hundred and Ten guns, $y^{*}$ Admirable of ninty Six and $y^{*}$ Terrible of ninty Six, and Two Privateers $y^{*}$ One of twenty four and ye other of Twenty Guns, as also a fireshp, He then stood outt of $y^{\circ}$ Bay and made way to joyn $y^{\circ}$ Fleett weh was then att Cape Barflleur, $y^{*}$ Thirteen Bayle of French Men of War haveing run aghore in a Bay Called La Honge.

On Monday $y^{2} 23^{2}$ of May 92.-Att Eleven this forenoon 8r John Ashby $w^{\text {th }} y^{t}$ partt of $y^{0}$ Fleett under his Comend Joyned $y^{\circ}$ Gener $r^{\text {ln }}$ Off 
of Cape Barffieur, $\mathrm{Sr}$ Ralph haveing done $\mathrm{y}^{\circ}$ same before. Att two this Affternoon a Consulltation was held onboard $y^{\circ} \mathrm{Adm}$ ll and they Came to these resollutions, viz That Vice Adm" Rooke should $\mathrm{y}^{\mathrm{t}}$ Evening Hoistt his Flag onboard of another Ship, and take $w^{\text {th }}$ him seven or Eightt sayle of small Friggatts and some fireshps, and also $y^{t}$ all $y^{0}$ Barges And Longbostts in $y^{\circ}$ Floett should be manned and goe $\mathrm{w}^{\text {th }}$ him into La Houge bay to Attemp $y^{\circ}$ burning of $y^{\circ}$ Thirteen ffrench Men of War $y^{t}$ was run afhore there. Bo according to $y^{\circ}$ Orders Vice Adm ll Rooke hed redd, aboutt Seven in $y^{\circ}$ Evening he stood into $y^{\circ}$ Bay, hsveing before hoistted his Flag onboard $y^{\circ}$ Eagle and Accompanyed as aforesaid. Att his Entrance In he mett $w^{\text {th }}$ Bome Opposition from a Plattform $y^{t}$ they had made to Obstructt our paisage, where they had Plantted severll of $y^{\circ}$ Ships Guns, but when he Came near he Answered them so warmly $y^{t}$ they soon quitted their Guns and afterwards did us Little damage, yo boatts Were Comanded by $y^{\circ}$ Lord Danby and Capt. Piokard haveing all of them fireworks Onbosrd, being Entred into $y^{\circ}$ Bay there was Another small Fortt $w^{\text {oh }}$ made some Refaisttance againstt us and $y^{*}$ Water being Shallow $y^{t}$ a Ship of force could not againstt itt $y^{e}$ Larke ffriggatt was Ordered to Lye and battr itt $w^{\text {oh }}$ she did $w^{\text {th }} g^{\text {ood }}$ succels, $y^{\circ}$ Bay was Lined $w^{\text {th }}$ Sonldiers both Horse and foott $w^{\text {oh }}$ fired Att us Amain without Intermifsion, butt notwithstanding their great Refsisttance, our Ships and boatts made an Assaullt upon $y^{\circ}$ French Ships, and by Ten att nightt sett Bix Bayle of them on fire one of $w^{\text {ch }}$ was $y^{*} \mathrm{~S}^{t}$ Phillip of a Hundred and odd Guns onbosed of $w^{\text {ch }} y^{\circ}$ Lrate King James this day dined $w^{\text {ch }}$ when they had Accomplished they Came outt and Anchored att $5^{\circ}$ month of $y^{\circ}$ bay all Nightt, by reason there was no more Ships in this Bay yo other seven Sayle haveing run ashore in a Little bay to $y^{*}$ Eastward of this; The Magazine in wh $^{\text {th }}$ was all $\mathrm{y}^{\circ}$ Powder $\mathrm{y}^{t}$ Came outt of $\mathrm{y}^{\circ}$ Thirtean ffrench Men of War blew up this night butt $y^{\circ}$ Cause we Cannot tell

On Tuesday $y^{*} 24^{4 k}$ of May 92 .- This morning our Ships and boatts made an Assaulltt upon $y^{\circ}$ residue of $y^{\circ}$ ffrench Men of War that was Left, being Seven sayle and Was very Hottly recd by $y^{\theta}$ forces $y^{t}$ Lined $y^{*}$ Shore, however by ton of $y^{\circ}$ Clock in $y^{\circ}$ morning we sett them all on fire together $w^{\text {th }}$ Seven anyle of Merchantt men, and one more we broughtt off and then stood outt of $y^{\circ}$ Bay, most of ye boatts Came off to $y^{\circ}$ Fleett $w^{\text {th }}$ ffrench Flaga in their bowes and good plunder, Att noon $y^{\circ}$ Fleott Came to sayle and stood for $\mathrm{S}^{\mathbf{t}}$ Hellens

FINIS

Of the Family of $y^{\circ}$ Rooks in Kent there were two $B^{n}$ Laurence \& William: Laurence had a fair Estate of $700^{\mathrm{ll}}$ a year, marryed $\mathrm{Sr}$ Peter Hammond's Daughter, by whom he had Hamnond Rook who prov'd an Atheistical swearing Man \& a great Bpender, marryed a. Coffeo-man's Daughter $w^{\text {th }}$ whom he liv'd nnessily \& discantentedly, so he or his father rather begun to sell $y^{\circ}$ Joyntare he had by his Grandmother to one $\mathrm{M}^{\mathrm{r}}$ Morris (of whom afterwards). Hammond Book then goes to

vOL. VII. -No. XXV. 
Tangier, comes back, is now in $y^{\circ}$ Regiment of $\mathrm{Sr}^{\mathrm{r}}$ Jonsthan Trelawny in Flanders; hath made love whether in reality or aport I know not to other women, who asking him $w^{t}$ he meant to do $w^{\text {th }} y^{0}$ Wife he had, Answered make minc'd Pies of her or a Fricasy; he hath however got money, \& would gladly buy back his Estate, bat Morris yo Proprietor will not sell:

Williem $\mathrm{y}^{\circ}$ other $\mathrm{B}^{\mathrm{r}}$ sometimes calld Coll ${ }^{l}$ Rook was in favour $w^{\text {th }} \mathrm{y}^{\circ}$ Duke of York, had but a small Estate saving $w^{t}$ he got from $y^{\circ}$ Court, he was Knighted by King James $2^{d}$ had 8 sons Georg Thomas \& Finch. Georg was a very unlucky Boy \& much given to stealing; his Father would have placd him w $^{\text {th }}$ an Attorney but he durst not trust him : At last he resolvd to send him to Sea \& being ask'd $y^{\circ}$ reason said he hed rather hear of his being drownd at Sea $y^{n}$ have him hangd at Lrand, so he was placd whilst a boy with $\mathrm{S}^{\mathrm{r}}$ Edward Sprag, \&c: This is he who was first a Capt" $^{n}$ of a Ship under K. James, then Rear Admiral, Vice Admiral, \& now $\mathrm{S}^{r}$ Georg Rook Admiral of yt Grand Fleet under King William 1697.

Mr Morris who bought part of $y^{\theta}$ Rooks Estate (as before noted) was a poor fellow, I think a Journey-man ont of employment \& was dejectedly sitting in an Inne whither Alderm ${ }^{n}$ Blackwell came accidentally \& asking him who he was \& whither going, He answered, into $y^{\circ}$ Countrey to my Freinds for here I can get no employment: Can $y^{\mathbf{u}}$ write $\&$ keep a Book (said $y^{\circ}$ Aldermon) Yes (said he) very well; hereupon he took Morris to his house $w^{n}$ he had but one poor shilling left in his Pocket. He staid $w^{\text {th }} y^{e}$ Alderman till he was able by piecemeal to by $y^{e}$ whole Estate of Laurence \& Hammond Rook; \& now he is said to be worth a thousend pound a Year; tho some think he overreachd \& rookd $\mathrm{y}^{\circ}$ Rooks before he got into their Nest, his Son proves prodigall his two Daughters foolish.

\section{A NONJUROR'S HIBTORY OF ENGLAND.}

THE revival of a sentimental attachment to the house of Stuart, and of an inclination to the doctrine of the divine right of kings, so soon as one and the other had ceased to be dangerous to the liberties and religion of the country, is among the phenomena of the second half of the eighteenth century. Among their causes may be enumerated the inevitable law of reaction; that tenderness towards a defeated party which invariably sets in when the practical issues of the struggle are at rest, which inspires Homer with romantic compassion towards Troy, and softens Virgil towards Carthage, and is now raising up panegyrists of Lee and Jefferson Davis to the north of the Potomac; above all the discovery that the maxims of the vanquished were exceedingly convenient for those by whom their champions had been displaced and dethroned. To the latter cause must be attributed the discouragement of Bishop Hayter's honest remonstrance (1752) against Jacobite books being offered for the perusal of his princely pupil. The protest which 